\title{
The Study of the Antimicrobial Properties of Selected Engineering Materials' Surfaces
}

\author{
Olawale Samuel Fatoba1,2*, David Ehigie Esezobor' ${ }^{2}$, Olaitan Lukman Akanji1, \\ Abiodun Joseph Fatoba3 ${ }^{3}$ Damilola Macgregor ${ }^{2}$, John Etubor ${ }^{2}$ \\ ${ }^{1}$ Department of Chemical, Metallurgical and Materials Engineering, Tshwane University of Technology, \\ Pretoria, South Africa \\ ${ }^{2}$ Department of Metallurgical and Materials Engineering, University of Lagos, Lagos, Nigeria \\ ${ }^{3}$ Deparment of Cell Biology and Genetics, University of Lagos, Lagos, Nigeria \\ Email: ${ }^{*}$ fatobaolawale@yahoo.com
}

Received 20 November 2013; revised 26 December 2013; accepted 7 January 2014

Copyright (C) 2014 by authors and Scientific Research Publishing Inc.

This work is licensed under the Creative Commons Attribution International License (CC BY).

http://creativecommons.org/licenses/by/4.0/

(c) (i) Open Access

\section{Abstract}

This paper studies the antimicrobial activity of selected engineering materials surfaces at room and chill temperatures. The antimicrobial effects of selected materials surfaces were evaluated by dropping the test pieces into prepared cultures of Bacillus spp, Escherichia coli, and Staphylococcus aereus isolated from fruits, animal feaces and natural environment respectively. Bacteria count obtained after $0,30,60,90,120,180,240$ and 300 minutes at room temperature and chill condition was taken and compared with their initial count. The amount of live bacteria drops by several orders of magnitude, to zero, on metallic copper and brass within 30 to 300 minutes in both room and chill conditions. In contrast, no reduction is seen in the number of colonies of live bacteria on plastics, ceramic and stainless steel in both room and chill conditions. These results suggest that the selection of metallic copper and brass for touch surfaces in hospitals, surfaces exposed to fruit processing and household utensils can materially assist in reducing bacterial contamination, which should lead to a reduction in the transmission of infectious organisms.

\section{Keywords}

Antimicrobial; Material Surfaces; Temperature; Bacteria; Environment

\section{Introduction}

Public concerns are over the threat of disease and infection posed by bacterial living on everyday objects such as

"Corresponding author.

How to cite this paper: Fatoba, O.S., Esezobor, D.E., Akanji, O.L., Fatoba, A.J., Macgregor, D. and Etubor, J. (2014) The Study of the Antimicrobial Properties of Selected Engineering Materials' Surfaces. Journal of Minerals and Materials Characterization and Engineering, 2, 78-87. http://dx.doi.org/10.4236/jmmce.2014.22012 
doorknobs, light switches, taps and work surface is on the rise. Apprehension is growing over E. coli, Streptococcus and Staphylococcus bacteria in hospitals, offices, gyms restaurants and homes, resulting in increased sales of anti-bacterial coatings, wipes, soaps and lotions-all of which eventually wear away and lose their effectiveness. The real concern is that about eighty percent of infections illnesses are transmitted by touch. Disease-causing bacteria are spread when contaminated individuals touch a surface, leaving behind germs to be picked up by the next person who touches that surface. The presence and spread of bacterial pathogens in hospitals are a growing problem the world over. Each year, hospital-acquired infections in the United Kingdom cost the National Health Services in the region of one billion pounds and at least five thousands patients die of complications from infections that they contracted in hospitals [1]-[4]. At any given time, nine percent of hospitalized patients in the UK (about 300,000) have an infection that they did not have before they arrived [5]-[9].

Not all hospital-acquired infections are preventable but about $45 \%$ reduction could be achieved through a series of infection control measures, including improved hygiene. Replacing frequently touched surface with copper alloys such as brasses and bronzes, copper-nickel and beryllium copper, and others which are believed to be naturally anti-microbial could be an important infection control measure and compliment other measures such as hand washing, patient screening and isolation, and improved cleaning. Metal ions, either alone or in complexes, have been used to disinfect fluid, solids, and tissues for centuries [10]. The ancient Greeks in time of Hypocrates (400 BC) were the first to discover the sanitizing power of copper. They prescribed copper and copper alloys for pulmonary diseases and for purifying drinking water. Gangajal (holy water taken from the Ganges River) is stored in copper alloy utensils in every Hindu house due to copper alloy's anti-fouling and bacteriostatic properties.

Investigations by [11]-[14] revealed the antimicrobial activity of copper and its alloys over other metals. Copper and its alloys act as a bacteria inhibitor in various food processes. The former surfaces inhibit the growth of two of the more prevalent bacteria pathogens that cause food borne diseases, Salmonelia entrica, Campylobacter jejuni, Escherichia coli, Staphylococcus aureus, Streptococcus group D and Pseudomas species [15]. However, stainless steel and aluminium commonly used in hospitals, homes and offices produced heavy microbial growth [16]-[18]. The bacteria pathogens investigated copper alloys and also metals and included Methicillin-resistance Staphylococcus aureus (MRSA) as studied by [1] [14] [16] [17], antibiotic-resistance "super bug” as reported by Keevil [16], Adenovirus, Influenza A and Listeria as investigated by [17].

Recognition of the bacteriostatic properties of copper and its alloys has led to testing its capacity as a water purifier. Copper alloys were found to be one of the most toxic metals to heterotrophic bacteria in aquatic environments [19] [20], and inhibited biofilm formation of Streplococcus sanguis as investigated by Milligan et al. [13]. Albright and Wilson [20] found that sensitivity to heavy metals of micro flora in water was (in order of decreasing sensitivity): Ag, Cu, Ni, Ba, Cr, Hg, Zn, Na, Cd. Sagripanti et al. [21] found that cupric chloride inactivated 9 of the 13 bacteria strains that they were tested by more than five logs within thirty minutes. The other four strains were inactivated to a lesser extent.

Copper and its alloys are considered safe to humans as demonstrated inter-alia by the widespread and prolonged use of copper inter-uterine device (IUDS) [22]. In contrast to the low sensitivity of human tissue (skin or others) to copper, micro-organisms are extremely susceptible to copper and its alloys as reported by Hostynek and Maibach [23]. This paper investigates the antimicrobial activity of selected engineering materials surfaces at room and chill temper.

\section{Materials and Method}

\subsection{Materials' Preparation}

Copper, brass, stainless steel plates, plastic and ceramic in form of plates were sourced and purchased from the local market. The materials were sectioned to a size of length $4 \mathrm{~cm}$, width $1 \mathrm{~cm}$ with thickness $0.5 \mathrm{~cm}$. The spectrometric analyses of the metals among the materials were done to determine their constituents or chemical composition. Table 1 shows the composition of the various metals for the experiment.

The test materials were autoclave. Autoclaving is a sterilization process, where pressure is used to produce high temperature of $121^{\circ} \mathrm{C}$ steam. It is based on the principle that when water is boiled at an increased pressure, the temperature at which it boils and of the steam it forms, rises. Hot saturated steam rapidly penetrates and gives up its latest heat when it condenses on cooler objects. Autoclave machine was used to sterilize the test material and to ensure the destruction of any bacteria on the test pieces prior to antimicrobial testing. The autoc- 
Table 1. Spectrometric composition of selected metals.

\begin{tabular}{ccccccccccccccc}
\hline Materials & \multicolumn{10}{c}{ COMPOSITION (\%) } \\
& $\mathrm{Fe}$ & $\mathrm{Cu}$ & $\mathrm{Zn}$ & $\mathrm{Mn}$ & $\mathrm{Mg}$ & $\mathrm{Ni}$ & $\mathrm{Si}$ & $\mathrm{C}$ & $\mathrm{Ti}$ & $\mathrm{Cr}$ & $\mathrm{P}$ & $\mathrm{Pb}$ & $\mathrm{S}$ \\
Copper & 0.005 & 99.9 & - & 0.005 & - & - & 0.0003 & - & - & - & 0.04 & 0.005 & - \\
Brass & 0.092 & 63.6 & 36.12 & 0.008 & 0.001 & 0.011 & 0.001 & 0.006 & 0.001 & 0.004 & 0.006 & 0.087 & 0.009 \\
$\begin{array}{c}\text { Stainless } \\
\text { Steel }\end{array}$ & 71.6 & - & - & 0.8 & - & 8.5 & 0.004 & 0.1 & - & 18.0 & - & - & 0.004 \\
\hline
\end{tabular}

lave machine was operated electrically.

\subsubsection{Microbes}

In order to prepare and grow the microbes for the antimicrobial test, culture media (nutrients agar and nutrient broth), slides, test-tubes, Petri-dishes, laboratory supplies and incubator were used. The nutrient agar with PH of $7.0+2$ was used to isolate the pure micro-organism from their environment and nutrient broth was used to cultivate them.

The culture media serves as a source of amino acids and nitrogen for the organisms. A thin layer of nutrient agar in a Petri-dish was used for growing of bacteria. The bacteria colonies shapes and counting was done without opening the lead of the Petri-dishes.

\subsubsection{Fruits Environment}

Apple, orange and mango were sourced and pure culture of bacteria was obtained from them. Sterilized wire loops were used to obtained drops of the fruits juice, and spread on 3 different disposable Petri-dishes containing the nutrient agar. Prior to spreading of the contents the wire loop was passed through a burner flame to sterilize it before and after collection of drops. The plates were covered and put in the incubator to grow the bacteria. Common bacteria associated and obtained from these fruits were Bacillus spp. This bacterium was known to cause endocarditic neonatal meningitis and bacteremia. Afterwards, a coloring of the bacteria was scrapped off the agar plate with the sterilized wire loop and dropped into the nutrient broth for culturing. The media used during microbes culturing are showed in Figure 1.

\subsubsection{Animal Feaces}

Water drops associated with human feaces were obtained from the toilet of Micro-Biology Department, University of Lagos (Figure 2). The drop of water obtained by the sterilized wire loop was spread on the prepared nutrient agar in Petri-dishes (plates) and inoculated to obtain fecal coliform known as Escherichia coli. A colony was subjected to culturing.

\subsubsection{Natural Environment}

Sterilized water left on an open surface for 90 minutes was incubated for 72 hours at a temperature of $37^{\circ} \mathrm{C}$ to obtain colonies of staphylococcus spp. The colony allowed to grow for 24 hours was cultured.

\subsection{Microbial Counting}

The colonies counting was done manually by counting the visible ones $0.1 \mathrm{ml}$ nutrient broth when view under a bright light as showed in Figure 3.

\subsection{Antimicrobial Testing}

Conical flask containing $50 \mathrm{ml}$ nutrient broth was prepared in fifteen places. Each microbe were placed in five separate broths and allowed to inoculate for 18 hours. The test samples were prepared in six pieces each and were sterilized in the autoclave to ensure the materials are free from other microbial contaminants.

\subsubsection{Antimicrobial Test at Room Temperature}

Copper, brass, stainless steel, plastic and ceramic dropped into each conical flash containing microbes from fruit, 


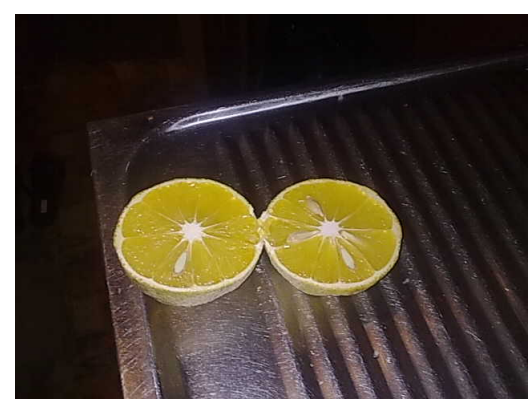

(a)

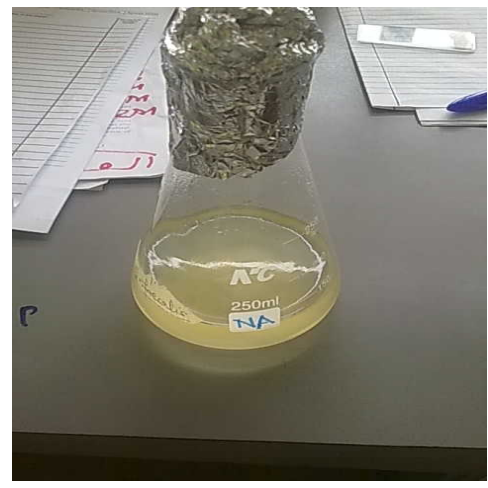

(c)

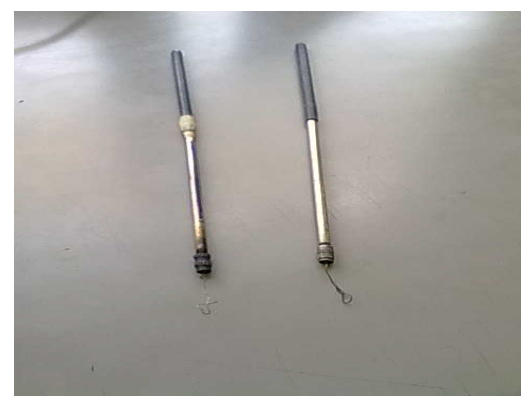

(b)

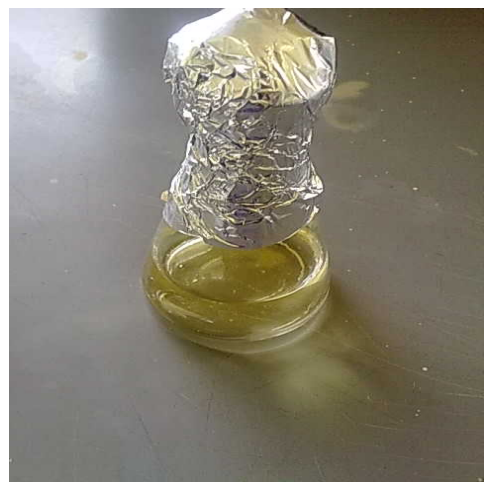

(d)

Figure 1. (a) Sectioned orange; (b) Wire loop; (c) Nutrient agar; (d) Nutrient broth.

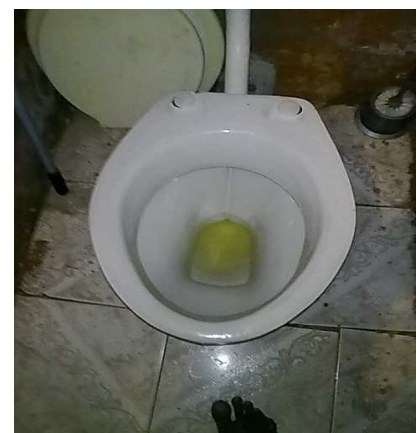

Figure 2. Toilet where fecal coliform was isolated.
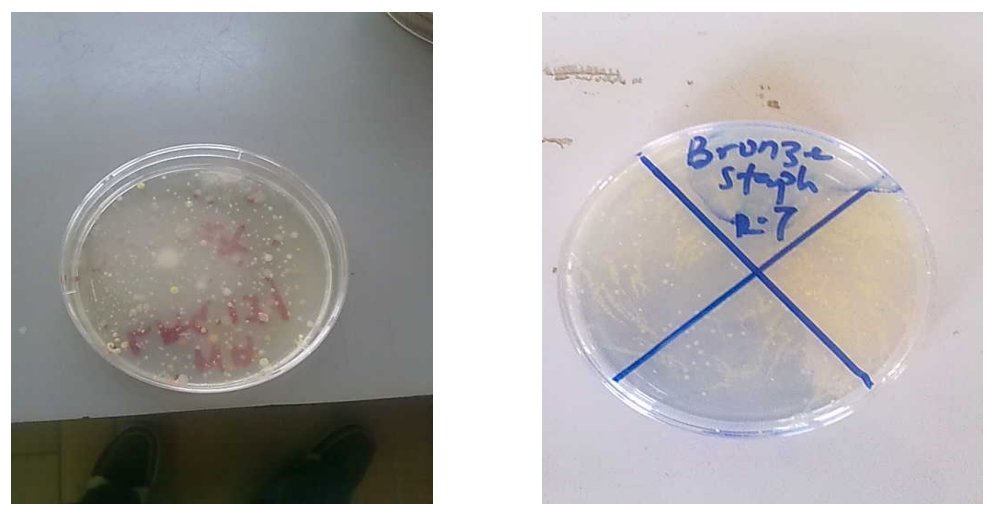

Figure 3. Colony forming units of microbes grown after inoculation. (a) Microbial growth; (b) Colony counting. 
animal feaces and natural environment was cultured. $0.1 \mathrm{ml}$ of the culture was taken in each flask after 30,60 , $90,120,180,240$, and 300 minutes, plated and placed in the incubator. The volumes collected and inoculated differently on the Petri-dishes for 18 hours were subjected to inoculation. After consecutive timing and respective inoculation, the numbers of colonies were counted for every test made.

\subsubsection{Antimicrobial Test at Chill Temperature}

Newly prepared cultures were placed in the refrigerator (Figure $4(\mathrm{~b})$ ) at a regulated temperature of $0^{\circ} \mathrm{C}-5^{\circ} \mathrm{C}$. $0.1 \mathrm{ml}$ of the cultured microbes was inoculated. The test materials were dropped immediately into respective cultures as that of the room temperature test and were subjected back to the chill environment (refrigerator). The process of further plating and inoculating was performed as same as the room temperature test. The numbers of colony formed were counted after 18 hours incubation.

\section{Results and Discussion}

The antimicrobial effects of the test materials were evaluated by dropping them into the culture of Bacillus spp, E. coli and Staphylococcus aureus. Bacterial counts (cfu/0.1 ml) obtained after 0, 30, 60, 90, 120, 180, 240 and 360 minutes were tabulated for normal room temperature and chill temperature.

In Figure 5, at room temperature copper had antimicrobial effects on $E$. coli (bacterial common with animal feaces). The decrease in colonies forming unit per $0.1 \mathrm{ml}$ was about $12 \mathrm{cfu} / 0.1 \mathrm{ml}$ in 30 minutes and proceeded to increase in the subsequent minutes. In 60 minutes, the decrease was $68 \mathrm{cfu} / 0.1 \mathrm{ml}$ which is about six times the

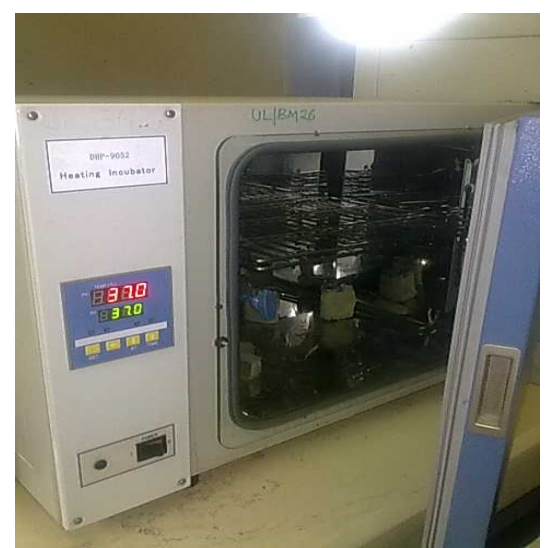

(a)

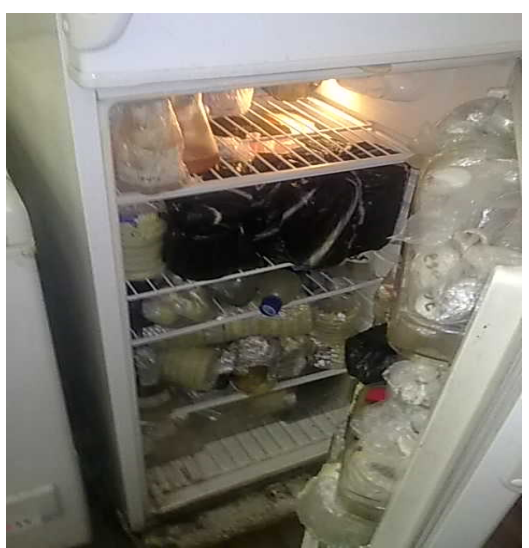

(b)

Figure 4. Pictures of incubator and refrigerator.

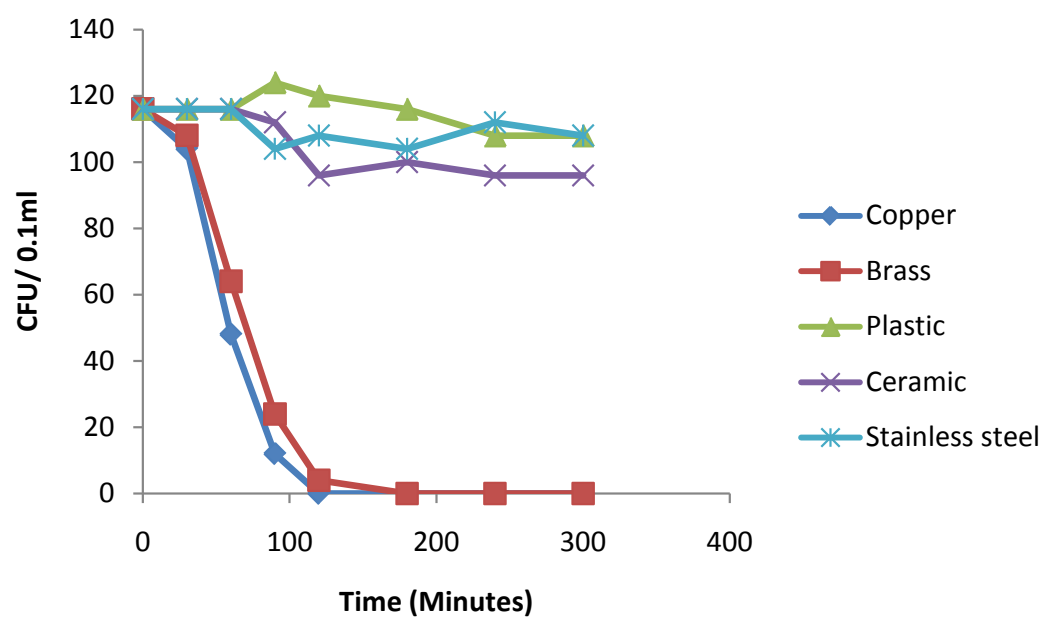

Figure 5. Test materials on E. coli. 
number inhibited at 30 minutes. At 120 minutes of exposure to copper surface, E. coli become inactive, and cannot grow in the plated volume and hence die.

In Figure 6, copper and brass had antimicrobial effects but with a decrease in the rate of inactivation. The killing of the microbes took a longer time than when at room temperature indicating that chill environment suppresses activity of copper and brass on the micro-organisms. However, other test materials show no antimicrobial effects both at room temperature and chill temperature. The number of colonies form unit per $0.1 \mathrm{ml}$ remains almost constant throughout the test time. The inhibitory mechanism of brass is similar to that of copper and brass kills the microbes due to the presence of copper present.

Figure 7 shows that at room temperature, copper surface reduce Bacillus spp by an amount of $58 \mathrm{cfu} / 0.1 \mathrm{ml}$ after 30 minutes. At an hour a half, the number of dead Bacillus had increased to about $96 \%$ of the original colonies present at Zero time. At 2 hours, there is no growth on the plated volume indicating that at 2 hours all microbes had died. The total number of colonies inactivated by copper at 2 hours was 182 which was originally present at zero time. Brass inactivated $50 \mathrm{cfu} / 0.1 \mathrm{ml}$ at 30 minutes (Figure 7) and kill about $91 \%$ of the original amount present at zero time. At room temperature, it kills completely all microbes present after 120 minutes. This is due to declination of membrane integrity of the microbes. This declination is caused by excess copper level in the pathogen as a result of the interaction with the copper or copper alloy surface. These declination leads to desiccation and subsequent cell death of the pathogen.

However, under chill condition similar inactivation was noticed in (Figure 8). However the rate of inactivation was slower than that of room temperature. At 30 minutes, the number of colonies reduced by copper and brass was $4 \mathrm{cfu} / 0.1 \mathrm{ml}$. The number increased by $11 \%$ for copper after an hour and $9 \%$ for brass after the same time. At 2 hours, more than half of the amount present at zero time had been killed by copper and brass surfaces. The total number of colonies present in the $0.1 \mathrm{ml}$ died at 6 hours (Figure 8). Plastics, ceramic and stainless steel used mostly in preparation and storage of fruits shows no effect on these microbes both at room temperature and chill condition. From Figures 7 and 8 , the number of cfu/ $0.1 \mathrm{ml}$ remains unchanged as microbes counting remain physically unchanged during the time intervals.

The viability of Staphylococcus spp was measured on the test materials surfaces. The results at room temperature are presented in Figure 9. The bacteria counts were taken at every 30 minutes interval starting from the zero time. Copper inhibit about $92 \mathrm{cfu} / 0.1 \mathrm{ml}$ in 30 minutes and at 90 minutes, $91 \%$ of bacteria had been killed. No bacteria count was observed at 120 minutes indicating that copper surfaces kills all living staphylococcus out of $220 \mathrm{cfu} / 0.1 \mathrm{ml}$ counted at zero time (Figure 9). After 90 minutes, about $78 \%$ of the amount counted at zero time had died. Figure 9 shows that only $48 \mathrm{cfu} / 0.1 \mathrm{ml}$ remain alive. Between 120 and 180 minutes, all staphylococcus bacteria with brass had died. At chill temperature, the rate of mortality of the bacteria is slower compare to that of room temperature. Copper kills $16 \mathrm{cfu} / 0.1 \mathrm{ml}$ as compared to $92 \mathrm{cfu} / 0.1 \mathrm{ml}$ in room temperature. At 90 minutes, only $22 \%$ of the colonies were inhibited as compared to $91 \%$ at room temperature. Copper was able to kill all staphylococcus bacteria between 180 and 240 minutes as compared to 120 and 180 minutes at room temperature. This is due to formation of an inhibiting layer by the copper/copper alloy which suffocates

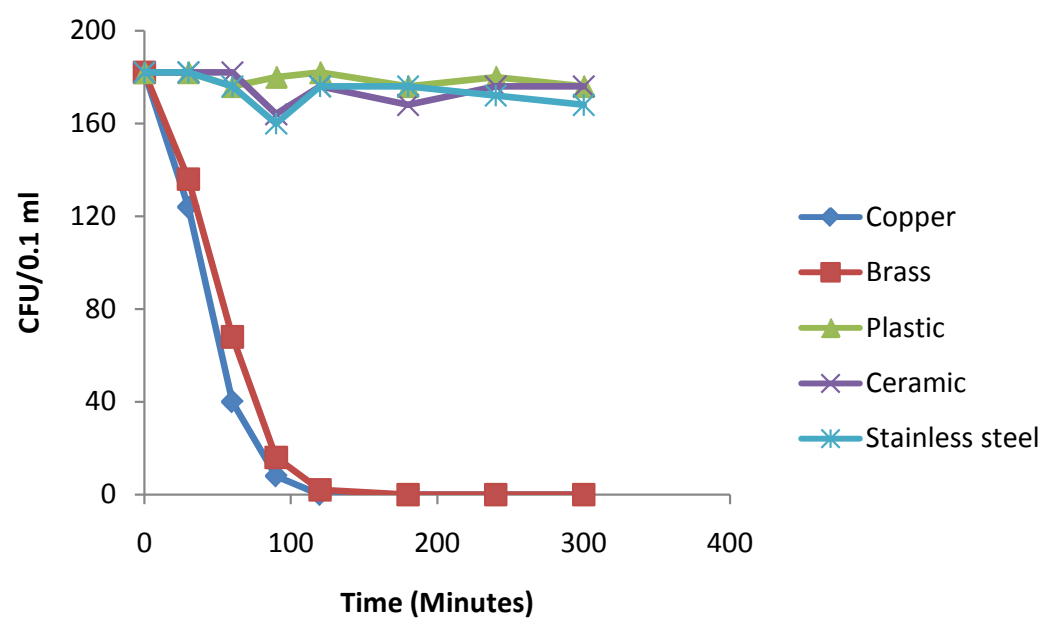

Figure 6. Test materials on E. coli. 


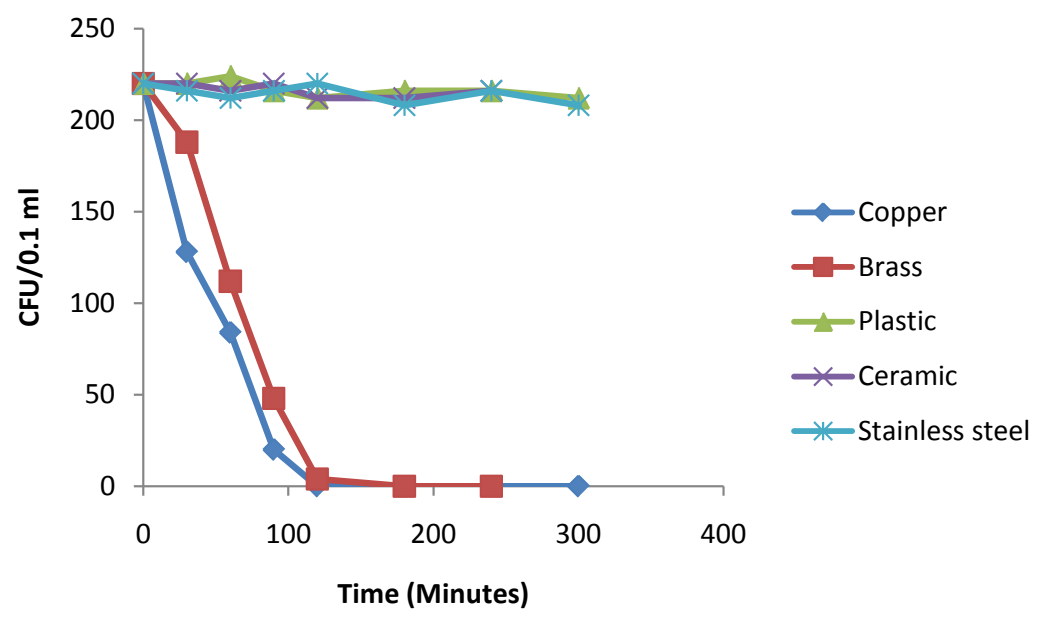

Figure 7. Test materials on Bacillus.

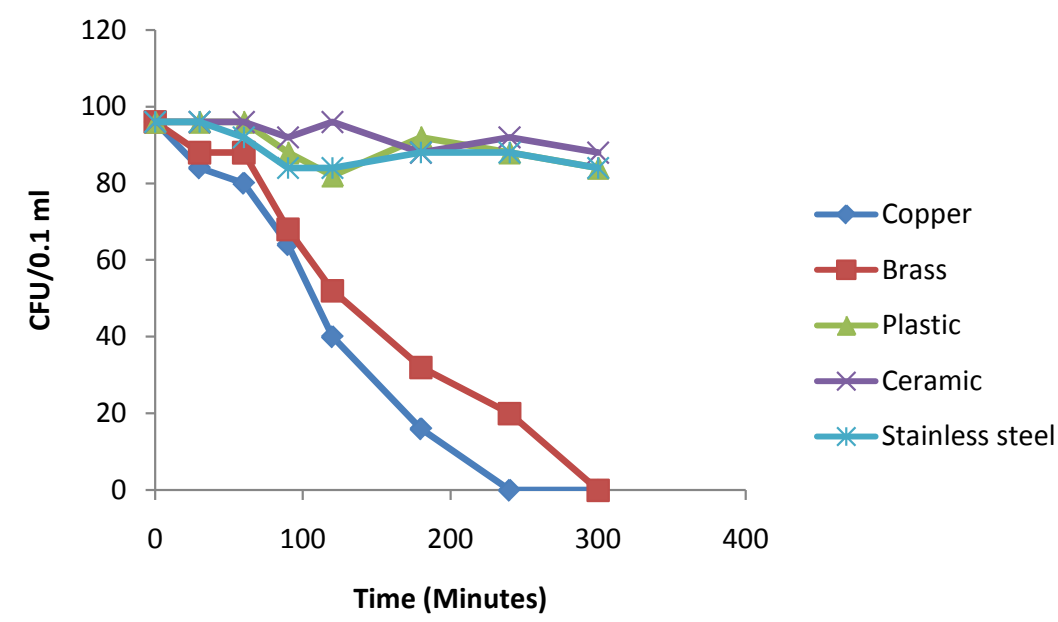

Figure 8. Test materials on Bacillus.

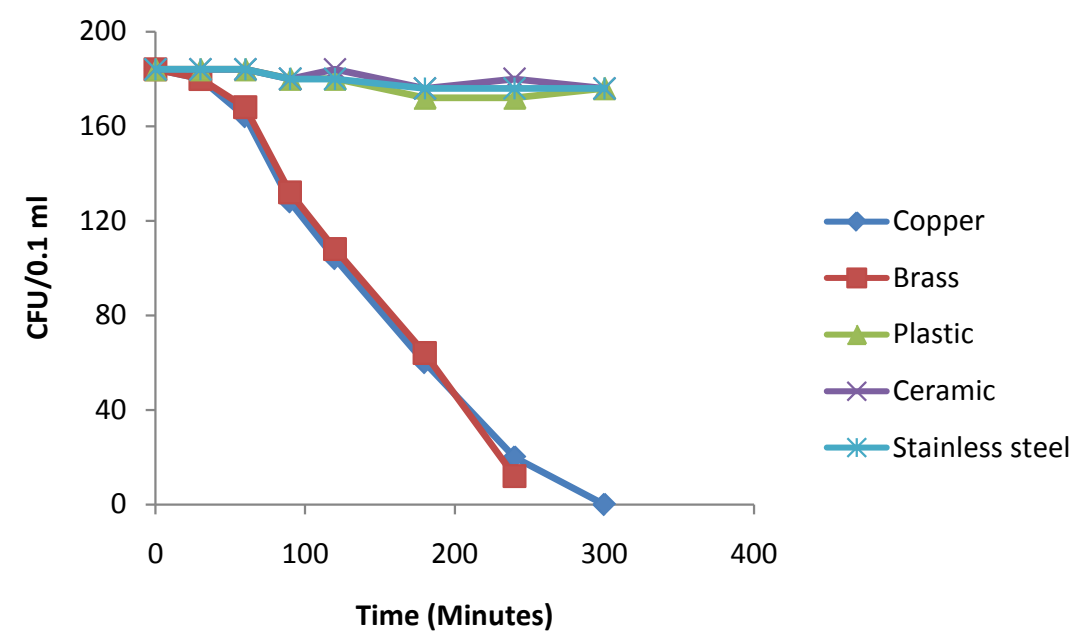

Figure 9. Test materials on Staphylococcus spp.

the pathogens subsequently leading to the death or inactivation as the case may be. Brass also had the same effect at chill temperature as compared to copper. The rate of inactivation of the bacteria was reduced (Figure 10). 
All bacteria were able to be killed by brass between 240 and 300 minutes. Plastic, ceramic and stainless steel shows no effect on the bacteria count at room temperature and chill temperature as number of bacteria count remains almost constant throughout the test duration (Figures 9 and 10).

The results of the test revealed a change in the appearance of culture on copper surfaces from the cream colour to pale blue colour and the metallic copper plate turned dark brown colour. This is indicative of the release of Copper ions, which was deeper with increasing time of exposure. This necessitate the determination of the effect of copper ions released in exposed food by testing the content of this metal(copper) released in meat samples. These antimicrobial properties of copper and its alloys occur via the oligodynamic effect, a toxic effect of metal ions on living cells and microbes. A very important process is the bonding of the metal surface to the pathogen. This bonding which is tagged "inappropriate bonding" leads to loss of function of the proteins in the pathogen. This eventually leads to a breakdown of the pathogen into non-functional protein portions.

Another possible mechanism for these antimicrobial characteristics is the declination of membrane integrity of the microbes. This leads to cell leakage of specific essential cell nutrients such as potassium and glutamate. This declination is caused by excess copper level in the pathogen as a result of the interaction with the copper or copper alloy surface. These declination leads to desiccation and subsequent cell death of the pathogen. Another process is the formation of an inhibiting layer by the copper/copper alloy which suffocates the pathogens subsequently leading to the death or inactivation as the case may be.

\section{Determination of the Absorption Rate of Copper Ions into Food (Meat)}

The process involved keeping the meat in a salt solution to stimulate wet condition, exposure of a predetermined amount (in weight) of meats on copper metal and analyzing the copper content in them after different time interval. After successive time interval of 1, 2, 3, 4, 5, and 6 hours, copper content of the meats was analyzed. The process of analysis involved sample ashing in a furnace at $550^{\circ} \mathrm{C}$ for 2 hours. The ash was then dissolved in distilled water and transferred to a conical flask, $5 \mathrm{ml}$ of nitric acid was added and sample boiled for 20 minutes. The boiled sampled was then transferred to $50 \mathrm{ml}$ volumetric flask containing distilled water.

The copper content of meat samples at various time intervals was determined using Spectra-AA-20 Atomic Absorption Spectrophotometer. Table 2 shows the value of copper content in the meat at various time intervals.

The analysis of residual copper in meat showed that effectively, there was an increase in the copper content of the meat with time reaching $1.04 \mathrm{mg} / 18 \mathrm{~g}$ after 4 hours of exposure (Figure 11). Copper acquisition was faster in the first 4 hours, then slower afterwards. After 5 and 6 hours, result shows that only a small increase compared to the value obtained at 4 hours was noticed. These results show that the copper adsorption by meat due to a continuous exposure to copper tends to reach a maximum after 4 hours. However, the recommended Dietary intake for copper is 0.9 , while the maximum limit of intake for this metal is $10 \mathrm{mg}$ as reported by Sullivan and Capenter [12]. Therefore an excessive copper release is therefore a limiting factor to consider.

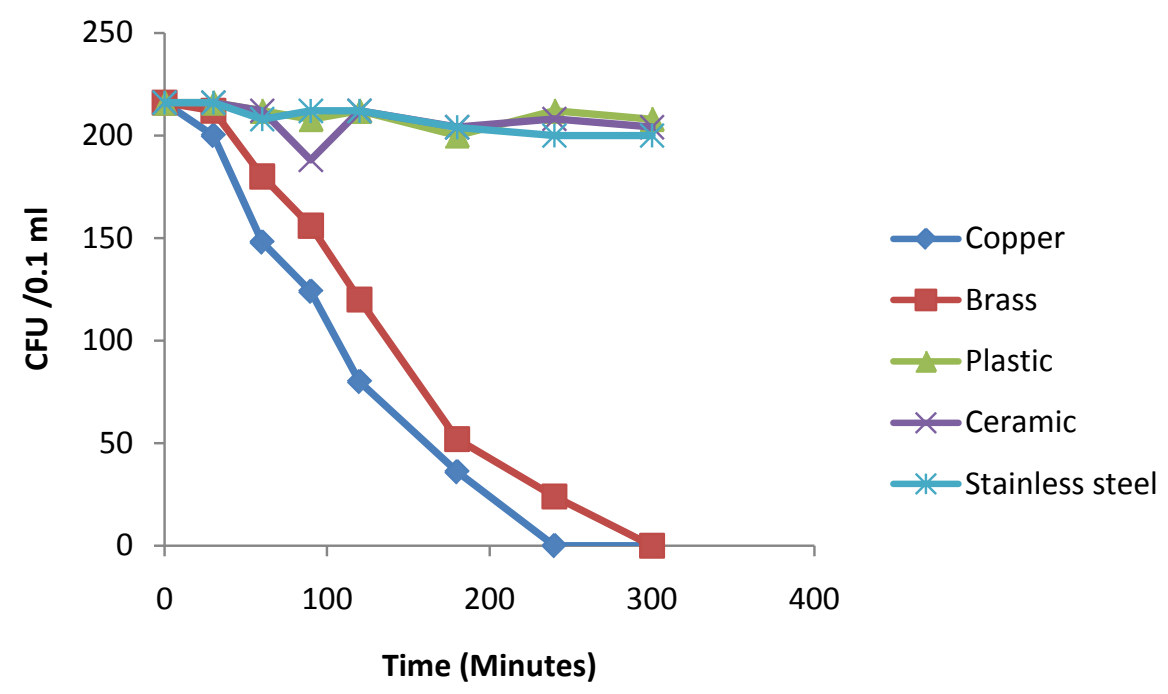

Figure 10. Test materials on Staphylococcus spp. 


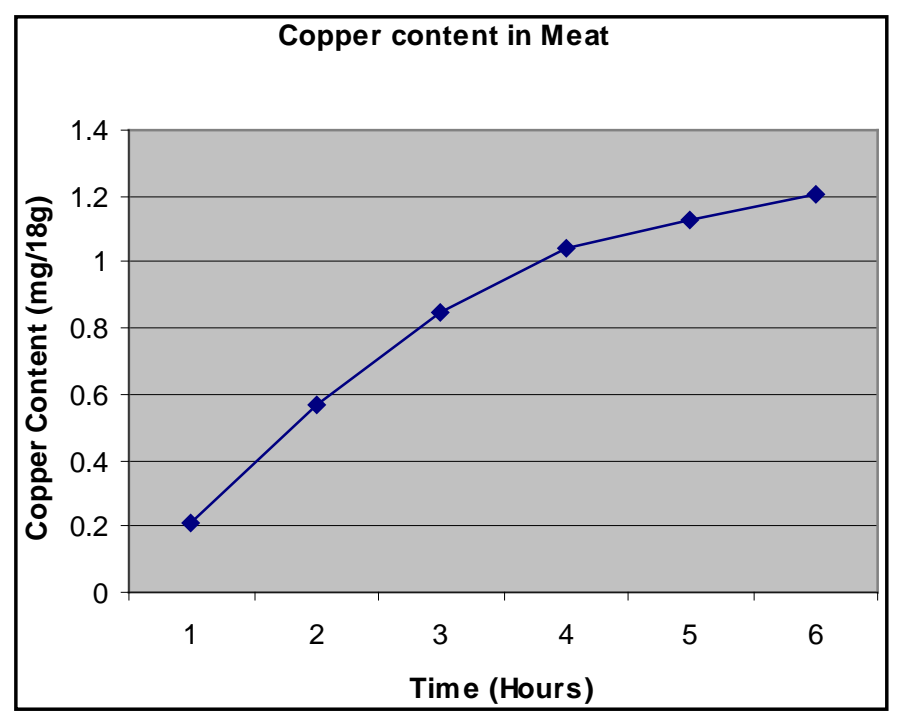

Figure 11. Copper content in meat.

Table 2. Copper content in meat.

\begin{tabular}{ccc}
\hline Weight of meat (g) & Time interval (hours) & Copper content (mg/18g) \\
\hline $18 \mathrm{~g}$ & 0 & 0.0052 \\
$18 \mathrm{~g}$ & 1 & 0.2100 \\
$18 \mathrm{~g}$ & 2 & 0.5679 \\
$18 \mathrm{~g}$ & 3 & 0.8501 \\
$18 \mathrm{~g}$ & 4 & 1.0399 \\
$18 \mathrm{~g}$ & 5 & 1.1242 \\
$18 \mathrm{~g}$ & 5 & 1.2064 \\
\hline
\end{tabular}

\section{Conclusions}

From the studies, the following conclusions can be made:

1) Metallic copper and brass surfaces exhibit antimicrobial properties and substantially kill microbes that come in contact with them.

2) Plastics, ceramics and stainless steel do not have antimicrobial effects and may permit a heavy growth of bacterial pathogens.

3) The potential use of metallic copper and brass as an inhibiting agent in the various stages of fruits processing operations, touch surfaces in hospitals and as toilets materials will reduce the rate of microbial transmission and infections.

4) Excessive copper releases to food are a limiting factor of using copper wraps to preserve food materials.

5) The copper absorption into food (meat) may exceed the maximum limit of intake of copper. For every $1 \mathrm{~kg}$ of meat, its absorption of copper for 6 hours will be $1.2 \mathrm{mg}$.

\section{References}

[1] Michels, H.T., Wilks, S.A., Noyce, J.O. and Keevil, C.W. (2005) Copper Alloys for Human Infectious Disease Control. Proceedings Materials Science and Technology Conference, Pittsburgh, 25-28 September 2005.

[2] Muller, F.L., Lustgarten, M.S., Jang, Y., Richardson, A. and Van Remmen, H. (2007) Trends in Oxidative Aging Theories. Free Radical Biology and Medicine, 43, 477-503. http://dx.doi.org/10.1016/j.freeradbiomed.2007.03.034

[3] Figueroa, G., Troncoso, M., Toledo, M., Lopez, C. and Lemus, S. (1998) Jejuni and Salmonella spp. in Broilers. Institute of Child Health, Cape Town, 373-376. 
[4] Domek, M.J., Robbins, J.E., Anderson, M.E. and McFeters, G.A. (1987) Metabolism of Escherichia coli Injured by Copper. Canadian Journal of Microbiology, 33, 57-62. http://dx.doi.org/10.1139/m87-010

[5] Cooney, T.E. (1995) Infection Control Hospital Epidemiol. Bactericidal Activity of Copper and Non-Copper Paint. 16th Edition, The University of Chicago Press, Chicago, 444.

[6] Wells, F. (2007) Preventive Veterinary Medicine. Midwest Resistance to Infection, 79, 204-223.

[7] Wilks, S.A., Michels, H. and Keevil, C.W. (2005) The Survival of Escherichia coli O157 on a Range of Metal Surfaces. International Journal of Food Microbiology, 105, 445-454. http://dx.doi.org/10.1016/j.ijfoodmicro.2005.04.021

[8] Higgins, R.A. (1992) Materials for Engineering Technician. 5th Edition, Hodder and Strughton, London.

[9] Block, S.S. (2001) Disinfection, Sterilization and Preservation. 9th Edition, Lippincott Williams Wilkins, Weston, 1857.

[10] Dollwet, H.H.A. and Sorenson, J.R.J. (2001) Historic Uses of Copper Compounds in Medicine. Trace Elements in Medicine. 2nd Edition, The Humana Press Inc., Arkansas, 80-87.

[11] Kuhn, P.J. (1983) Doorknobs: A Source of Nosocomical Infections. Diagnostic Medicine. Medical Economics Co., Montvale.

[12] Sullivan, D. and Carpenter, D. (1993) Method of Analysis for Nutrition Labeling. AOAC International, Arlington.

[13] Milligan, A.M., Wilson, M. and Knowles, J.C. (2003) The Effect of Increasing Copper Content in Phosphate-Based Glasses on Biofilms of Streptococcus sanguis. Biomaterials, 24, 1797. http://dx.doi.org/10.1016/S0142-9612(02)00577-X

[14] Mehtar, S., Wild, I. and Todorov, S.D. (2008) The Antimicrobial of Copper and Copper Alloys against Nosocomial Pathogens and Mycobacterium Tuberculosis Isolated from Healthcare Facility in the Western Cape: An in-vitro Study. Journal of Hospital Infection, 68, 45.

[15] Mulligan, M.E., Murray-Leisure, K.A., Ribner, B.S., Standiford, H.C., John, J.F., Korvick, J.A., Kauffman, C.A. and Yu, V.L. (1993) Methicillin-Resistant Staphylococcus aureus: A Consensus Review of the Microbiology, Pathogenesis, and Epidemiology with Implications for Prevention and Management. The American Journal of Medicine, $94,313$. http://dx.doi.org/10.1016/0002-9343(93)90063-U

[16] Keevil, C.W. (2002) Encyclopedia of Environmental Microbiology. Pathogens in Environmental Biofilms. Wiley, New York, 2339-2356.

[17] Avakyan, Z.A. and Rabotnova, V. (1966) Determination of the Copper Concentration Toxic to Micro-Organisms. Microbiology, 35, 682-687.

[18] Cooney, J.J. and Tang, R.J. (1999) Methods Enzymol. 3rd Edition, The University of Chicago Press, Chicago, 637.

[19] Michels, H.T. (2006) Anti-Microbial Characteristics of Copper. ASTM Standardization News, 28-31.

[20] Albright, L.J. and Wilson, E.M. (2001) Water Resistance. 8th Edition, Kluwer Academics Publisher, Amsterdam, 101.

[21] Sagripanti, J.L., Routson, L.B. and Lytle, C.D. (2001) Infection Control. 2nd Edition, International Copper Research Association, 335.

[22] Bilian, X. (2002) Intrauterine Devices. Best Practice and Research Clinical Obstetrics and Gynaecology, 16, $155-168$.

[23] Hostynek, J.J. and Maibach, H.I. (2003) Revolution in Environmental Health. 18th Edition, John Wiley \& Sons, Hoboken, 153. 